\title{
Therapeutic plasma exchange for the treatment of pediatric renal diseases in 2013
}

\author{
Caitlin E. Carter • Nadine M. Benador
}

Received: 21 November 2012 /Revised: 1 March 2013 /Accepted: 26 March 2013 /Published online: 29 June 2013

(C) IPNA 2013

\begin{abstract}
Therapeutic plasma exchange is an extracorporeal treatment modality that removes systemic circulating pathologic factors or replaces absent plasma components and plays a role in many nephrologic conditions. It presents a number of technical challenges in the pediatric population but has become an increasingly common practice in pediatric nephrology over the past several decades. While prospective evidence is often lacking, our increased understanding of the molecular pathogenesis underlying many pediatric renal diseases provides sound reasoning for the use of plasma exchange in treating these conditions. This review will present the currently accepted indications for plasma exchange in children, the technical aspects of the procedure and its potential complications.
\end{abstract}

Keywords Plasma exchange $\cdot$ Renal transplant $\cdot$ Renal indications · FSGS · atypical HUS · TTP · AMR

\section{Brief history of plasma exchange}

The first plasmapheresis procedure was reported in 1914 at Johns Hopkins University. Whole blood was manually removed from donor horses and centrifuged; the isolated erythrocytes were suspended in buffer and returned to the horse and plasma was conserved to be used as antitoxic sera [1]. Over the following decades, significant advancements in technology and transfusion science directed at the collection of human blood products for transfusion were achieved and later applied to plasma exchange. In 1960, the first

C. E. Carter $\cdot$ N. M. Benador $(\bowtie)$

Division of Pediatric Nephrology, Department of Pediatrics, University of California San Diego-Rady Children's Hospital, 3030 Children's Way,

San Diego, CA 92123, USA

e-mail: nbenador@ucsd.edu human treatment with plasma exchange was reported in a patient with Waldenstrom's macroglobulinemia [2]. Later that decade, a continuous-flow centrifugal apparatus was developed which has been modified over time to become the Cobe Spectra. Further refinements in the technology and advancements in our understanding of disease processes over the last three decades have made plasma exchange an important and safe treatment modality for children with renal and other immune-mediated diseases.

\section{Indications and evidence for therapeutic plasma exchange in children}

During therapeutic plasma exchange (TPE) whole blood is removed from the patient and passed through an extracorporeal medical device, which separates the plasma from the cellular components of the blood. The plasma is removed and replaced with a colloid solution (e.g. albumin and/or donated plasma) or a combination of crystalloid and colloid solutions [3]. The cellular components are returned to the patient. By removal of plasma, TPE non-selectively removes large molecular weight substances from the intravascular space. In clinical practice, there are two rationales for using TPE: to remove an inciting circulating pathogenic molecule (antibody, immune complex, toxin, etc.) or to replace a deficient factor, as in systemic thrombotic microangiopathy. TPE has been reported or investigated for use in a broad range of disease processes, and the list of indications is evolving as the underlying pathology of disease processes are discovered and more therapeutic trials are conducted. In addition, as new immunologic therapies are discovered and tested, TPE may cease to be the first-line treatment for some of these conditions. In some conditions TPE has not been proven to be beneficial, particularly in children, and the detailed pathophysiology of these is beyond the scope of this article. This 
review will focus on the conditions most pertinent to the pediatric nephrologist for which TPE is an accepted or recommended therapeutic modality. These include removal of preformed cytotoxic antibodies in the renal transplant candidate [anti-donor human leukocyte antigen (HLA) or ABO antibodies, or high panel reactive antibody], antibodymediated renal allograft rejection, recurrent focal segmental glomerulosclerosis (FSGS) after renal transplantation, antineutrophil cytoplasmic antibodies (ANCA) and antiglomerular basement membrane antibody-associated rapidly progressing glomerulonephritis, and atypical hemolytic uremic syndrome (aHUS). We will briefly discuss lupus nephritis, for which TPE is currently not a recommended treatment, as well as immunoglobulin A (IgA) nephropathy, HenochSchönlein purpura (HSP) and sepsis with multi-organ failure, which are less well studied.

The American Society for Apheresis (ASFA) Special Issue, 5th Edition, published in 2010, includes a comprehensive review of the available literature for each disease process. ASFA classifies disorders into four categories, based on the quality of the available literature and the strength of the society's recommendation for TPE in each disorder. Category I includes disorders for which apheresis is accepted as firstline therapy; category II includes disorders for which apheresis is accepted as second-line therapy; category III includes disorders for which the optimum role of apheresis is not established and decision-making should be individualized; category IV includes disorders for which evidence demonstrates or suggests that apheresis is ineffective or harmful and should not be initiated without Institutional Review Board approval [3]. A list of conditions for which TPE is recommended (Category I or II) by ASFA is provided in Table $1[3,4]$. A summary of the disease processes and current treatment recommendations is provided in Table 2.

\section{Renal transplant patients}

Indications prior to renal transplantation

\section{Desensitization for patients with high panel reactive antibody or positive cross-match}

Concomitant with the improved survival rate after pediatric renal transplantation, more patients are requiring repeat transplantation. Exposure to foreign HLA antigens by previous organ transplant, blood transfusion or pregnancy induces the production of antibodies to HLA antigens of potential donors. The presence of these antibodies is a risk factor for acute antibody-mediated rejection (AMR), and patients with higher panel reactive antibody (PRA) spend more time waiting for kidney transplant than those with lower PRA [5]. Pre-transplant plasma exchange has been used in patients who are highly HLA sensitized to reduce donorspecific antibody levels and allow for successful renal transplantation, either from the deceased donor pool (by lowering PRA) or from a potential living donor (by eliminating a positive cross-match). In several studies of adult patients with high PRA, protocols including TPE (with low-dose intravenous immunoglobulin (IVIG) \pm anti-CD20 therapy) have been shown to be superior to treatment with IVIG alone for desensitization with the goals of lowering donor specific antibodies (DSA) levels, reducing PRA, achieving a negative cross-match, avoiding post-operative AMR and prolonging graft survival [6-8]. A recent series of adult patients with end-stage renal disease (ESRD) demonstrated that patients who underwent desensitization with TPE and IVIG followed by living donor kidney transplantation had significantly improved survival than those who remained on dialysis and waited for an HLA-compatible deceased donor [9]. Desensitization is not well studied among children, but TPE allowed a successful second renal transplant in an 11 year-old girl whose PRA was not sufficiently reduced with high-dose IVIG [10]. Medical therapy with high-dose IVIG and rituximab has been proposed as an alternative to serial TPE treatments for patients awaiting deceased donor renal transplantation $[11,12]$. Among adult patients, desensitization is becoming an accepted method to expand the donor pool and thus decrease waiting time for kidney transplantation [13]. Whether the benefits of desensitization would also be observed in the pediatric population with ESRD is as yet unknown; children are less likely to have had potentially sensitizing exposures and generally spend less time waiting for an organ from a deceased donor, making the need for desensitization relevant for only a narrow population. However, for individual children who have donor-specific HLA antibodies to a potential living donor, TPE is an increasingly accepted treatment to overcome that barrier to transplantation.

\section{ABO-incompatible living donor renal donation}

ABO-incompatible living-donor kidney transplantation is another strategy to overcome barriers to renal transplantation and has become more frequent despite an increased risk of hyperacute or acute humoral graft rejection due to preformed antibodies to endovascular oligosaccharides [14]. Reduction of Immunoglobulin G (IgG) and Immunoglobulin M (IgM) titers to below 1:4 is recommended to prevent these adverse outcomes, because higher levels have been associated with acute rejection and worse graft survival [3,15-17]. Antibody reduction with TPE is followed by rituximab therapy or splenectomy to minimize antibody synthesis in the peritransplant period. Treatment with TPE results in lower isoagglutinin titers, low rates of hyperacute rejection and AMR, although randomized clinical trials have not been 
Table 1 Indications for therapeutic plasma exchange in children

\begin{tabular}{|c|c|}
\hline Renal diseases & Other conditions \\
\hline Renal transplant conditions & Hematologic \\
\hline ABO-incompatible kidney transplant ${ }^{\mathrm{a}}$ & ABO-incompatible stem cell transplant \\
\hline Pretransplant desensitization $^{\mathrm{a}}$ & Aplastic anemia (pure red cell aplasia) \\
\hline Antibody-mediated rejection ${ }^{\mathrm{a}}$ & Autoimmune hemolytic anemia (Cold agglutinin) \\
\hline Recurrent focal segmental glomerulosclerosis ${ }^{\mathrm{a}}$ & Catastrophic antiphospholipid antibody syndrome \\
\hline Immune-mediated glomerular disease & Hyperviscosity in monoclonal gammopathies \\
\hline Anti-glomerular basement membrane disease ${ }^{a}$ & Post-transfusion purpura \\
\hline ANCA-associated rapidly progressive glomerulonephritis ${ }^{a}$ & Red cell alloimmunization in pregnancy \\
\hline IgA nephropathy ${ }^{\mathrm{a}, \mathrm{b}}$ & Neurologic \\
\hline Henoch-Schonlein purpura nephritis ${ }^{\mathrm{a}}$ & Acute disseminated encephalomyelitis \\
\hline Other immune-mediated glomerulonephritis ${ }^{\mathrm{a}, \mathrm{b}}$ & Chronic focal encephalitis \\
\hline Cryoglobulinemia & Guillain-Barre syndrome \\
\hline Other & Chronic inflammatory demyelinating polyneuropathy \\
\hline Atypical hemolytic uremic syndrome ${ }^{a}$ & Multiple sclerosis \\
\hline Sepsis with multiorgan failure ${ }^{a, b}$ & Lamber-Eaton myasthenic syndrome \\
\hline Thombotic thrombocytopenic purpura $^{\mathrm{a}}$ & Lupus cerebritis \\
\hline \multirow[t]{14}{*}{ Myeloma cast nephropathy } & Neuromyelitis optica \\
\hline & Myasthenia gravis \\
\hline & PANDAS, Sydenham's chorea \\
\hline & Paraproteinemic polyneuropathies (IgG/IgA, IgM) \\
\hline & Metabolic \\
\hline & Familial hypercholesterolemia (homozygotes, small blood volume) \\
\hline & Mushroom poisoning \\
\hline & Refsum's disease \\
\hline & Wilson's disease, fulminant \\
\hline & Solid organ transplant \\
\hline & ABO-incompatible heart transplant \\
\hline & Antibody-mediated heart transplant rejection \\
\hline & Other \\
\hline & Lupus with diffuse alveolar hemorrhage \\
\hline
\end{tabular}

ANCA, Anti-neutrophil cytoplasmic antibodies; IgA, immunoglobulin A;

${ }^{a}$ Discussed in the text

${ }^{b}$ Disorders are categorized in American Society for Apheresis (ASFA) category III, but are included in this table because they are discussed in the text

performed $[18,19]$. The largest case series of pediatric patients who received ABO-incompatible renal transplants included 52 Japanese children who were treated with three to four plasma exchange treatments (goal anti-A/B titers of $<1: 8)$ prior to transplant. Compared with $\mathrm{ABO}$-compatible recipients during the same time period there were higher rates of AMR among the former, but 10-year outcomes were not significantly different [20]. The same center previously reported 16 pediatric $\mathrm{ABO}$-incompatible living kidney transplants treated with plasma exchange or immunoabsorption prior to transplantation and splenectomy at the time of transplantation. The majority ( $56 \%$ ) had an increase in anti-ABO titers with an associated increase in serum creatinine (presumed AMR), and one child suffered graft loss due to delayed hyperacute rejection, although the 10-year graft survival was similar to that of ABO-compatible transplantation [21]. These data are consistent with data from adult series [20, 22]. The use of antigen-specific column absorption, as opposed to TPE, to reduce ABO antibody titers before transplantation has also been recently reported to be successful in adults and children [23, 24].

Indications after renal transplantation

\section{Acute antibody-mediated rejection}

Acute AMR occurs in approximately $10 \%$ of all renal transplant recipients and in up to $30 \%$ of patients who have 


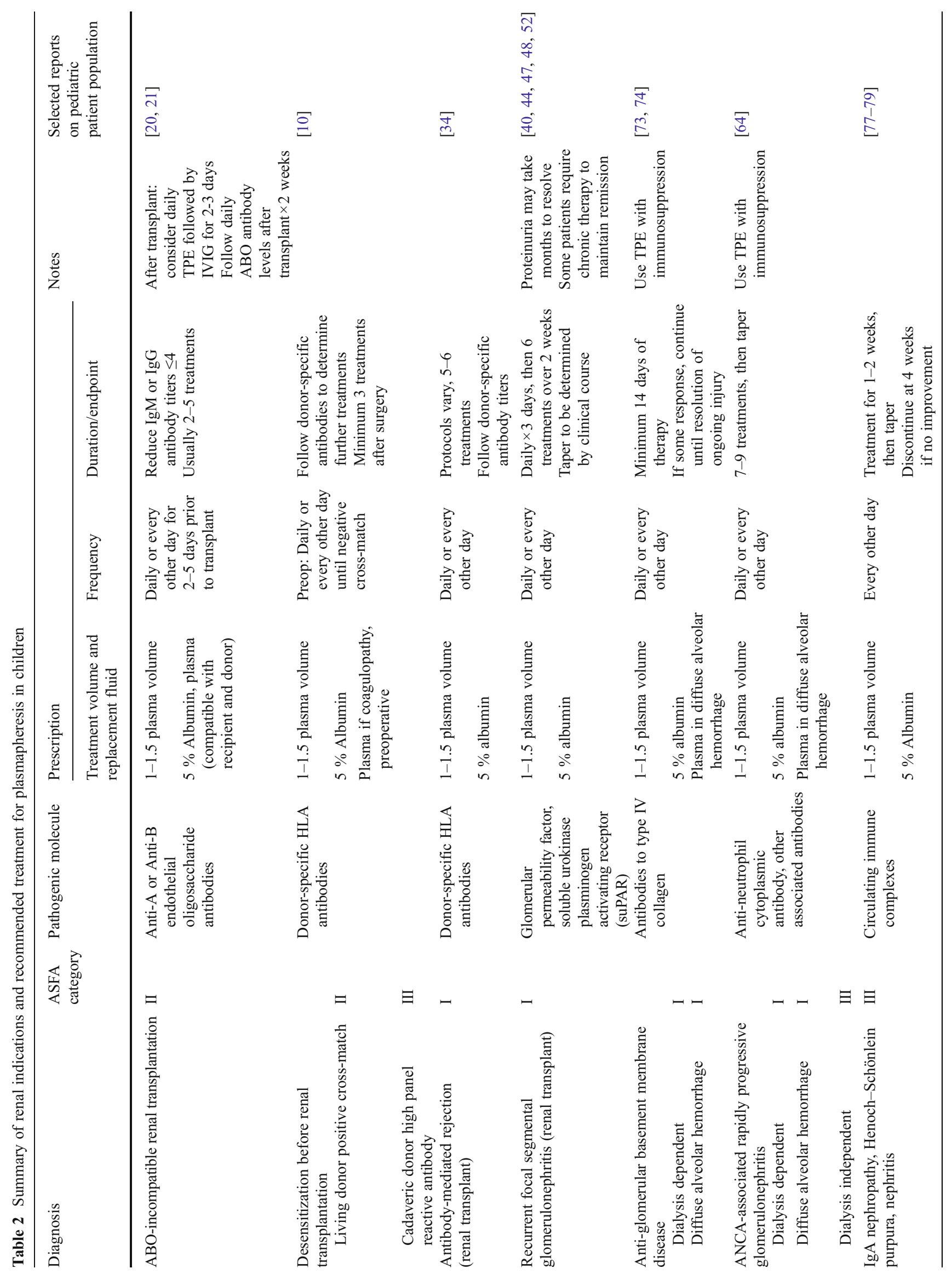


undergone desensitization for known donor-specific HLA antibodies [11, 25]. AMR is most commonly caused by antidonor HLA antibodies, although other endothelial targets have also been identified [26, 27]. The diagnosis of AMR is based on decreased graft function, positive donor-specific antibodies, and histological changes, including $\mathrm{C} 4 \mathrm{~d}$ positive staining of peritubular capillaries, graded according to Banff 07 criteria on renal biopsy [28]. The role of plasma exchange in treating AMR varies by center. TPE achieves rapid reductions in circulating antibody levels, but concurrent medical therapy aimed at reducing antibody production is also required, including corticosteroids, IVIG and rituximab. At Cedars-Sinai TPE is used in severe AMR, including those cases of patients showing a rapid decline in renal function and more severe abnormalities on kidney biopsy, while patients with less severe cases are treated with medical therapy (pulse steroids, IVIG and rituximab) [29]. Other centers include TPE as part of the regimen for all cases of AMR [30]. AMR generally responds well, and recovery of renal function has been reported in $>80 \%$ of patients for whom TPE was included in their therapy [31-33]. Kranz et al. reported four episodes of AMR in three pediatric renal transplant recipients with acute renal failure shortly after renal transplantation [34]. All were treated with pulse steroids, IVIG, rituximab and plasma exchange, and three had preserved graft function. In another study, TPE used in conjunction with IVIG and antiCD20 antibody was better than IVIG alone in lowering donorspecific antibodies and prolonging graft survival in subjects with acute AMR [35]. Emerging therapies in the treatment of AMR include immunoadsorption for antibody removal [36], and eculizumab and bortezomib to target antibody synthesis and effect $[25,29]$.

\section{Post-transplant recurrence of FSGS}

Idiopathic (primary) FSGS is caused by a circulating factor that increases glomerular permeability to albumin, with recent data strongly implicating overexpression of soluble urokinase plasminogen activating receptor (suPAR) in the pathogenesis of FSGS in adults and children [37, 38]. FSGS accounts for $9 \%$ of pediatric patients with ESRD receiving a transplant in North America, and children with ESRD secondary to FSGS have a high rate (30-86\%) of recurrence of proteinuria after renal transplant [39-42]. Graft failure is more common among patients with recurrence, and the duration of graft survival is lower among patients with FSGS than among those with other causes of glomerular disease [43, 44]. Treatment with plasma exchange reduces proteinuria and prolongs graft survival in pediatric case series and is most successful in preserving renal function in patients who are treated early after recurrence is diagnosed [42, 45-48]. Greenstein et al. [47] reported recurrence in $40 \%(8 / 20)$ of pediatric patients who underwent renal transplantation for ESRD secondary to FSGS. TPE was 
performed in six of those patients, with five of the six achieving remission and more rapid remission achieved in patients who were treated in the first $48 \mathrm{~h}$ after diagnosis of relapse [47]. Cochat et al. [49] reported similarly promising results in another case series of three pediatric patients with recurrent FSGS within 2 weeks of renal transplant; all patients were treated with TPE, and all achieved remission and had preserved renal function. Recurrence of FSGS is associated with worse graft outcomes, and achieving remission may improve graft survival [50].

The use of prophylactic TPE in patients at risk for FSGS recurrence has also been evaluated in children. In a study of Japanese children, the rate of recurrence of FSGS in renal transplant recipients was $33 \%$ in the group who received TPE prior to transplantation, compared with $66 \%$ among those who did not receive prophylactic or early TPE [51]. Couloures et al. reported a single case of a patient at high risk for recurrence treated with pre-transplant TPE who did not have recurrence of proteinuria after transplantation [52]. The described clinical risk factors for recurrence of FSGS after kidney transplantation include younger age of onset of disease, race, rapidity of progression and lack of genetic mutations to explain nephrotic syndrome. Patients with podocin mutations may be at lower risk of recurrence [53]. However, recurrence is still unpredictable, making identification of those who would benefit from prophylactic TPE difficult [48, 54, 55]. Prophylactic TPE would likely be most beneficial in patients with a history of recurrent FSGS in a previous transplant [56] or in those with an identified glomerular permeability factor [54, 57].

\section{Immune-mediated glomerulonephritis}

ANCA-associated rapidly progressive glomerulonephritis

Anti-neutrophil cytoplasmic antibodies-associated renal disease is characterized by a rapid loss of renal function, crescents on light microscopy with minimal glomerular immune deposits on immunofluorescence ('pauci-immune') on renal biopsy and presence of serum ANCA [cytoplasmic (c)-ANCA or perinuclear (p)-ANCA]. The disease spectrum includes granulomatosis with polyangiitis (GPA, previously known as Wegener's granulomatosis), microscopic polyangiitis and Churg-Strauss syndrome. The primary treatment for ANCAassociated vasculitis with non-dialysis-dependent renal disease is immunosuppression, but TPE may be beneficial for patients who are dialysis dependent or have diffuse alveolar hemorrhage, a potentially life-threatening complication of ANCA-associated diseases.

To date there have been no trials of TPE for the treatment of ANCA-mediated renal disease in children, and data from studies of adult patients are conflicting. However, two recent adult reports have shown that patients with severe renal dysfunction (requiring dialysis [58] and a serum creatinine concentration of $>5.8 \mathrm{mg} / \mathrm{dL}$ [59]) from ANCA-mediated disease who were treated with TPE have a higher likelihood of renal recovery. Other older studies did not show a benefit of treatment with TPE $[60,61]$.

In a case series of 25 children with GPA, two children who were dialysis dependent at the time of diagnosis were treated with plasma exchange and subsequently showed sufficient improvement in their renal function to allow termination of hemodialysis for the long term [62]. In this report, the three other children who presented requiring dialysis and were not treated with TPE did not recover renal function. Other smaller series have reported children with ANCA-associated glomerulonephritis responding to therapeutic regimens that included TPE $[63,64]$. Given the poor prognosis of ANCA-associated glomerulonephritis, a trial of TPE is reasonable even without strong supporting evidence. A large clinical trial for patients 15 years and older is currently in the recruiting process to better determine the benefits of TPE in ANCA-associated vasculitis (Clinicaltrials.gov NCT00987389).

Anti-glomerular basement membrane antibody glomerulonephritis

Anti-glomerular basement (anti-GBM) antibody syndrome is characterized by linear IgG deposits to type IV collagen on renal biopsy. It presents as rapidly progressive glomerular nephritis, usually associated with diffuse alveolar hemorrhage, although $30-40 \%$ of cases do not have pulmonary involvement [65]. This syndrome was discovered to be an antibodymediated disease in the 1960 s, and at that time patients had a dismal prognosis. Since the 1970s, TPE, in conjunction with immunosuppression (usually corticosteroids and cyclophosphamide), has become a mainstay of therapy. TPE is effective in lowering circulating antibody levels and decreasing pulmonary hemorrhage in children and adults [66, 67]. The only clinical trial comparing treatment with TPE + immunosuppression to treatment with immunosuppression alone demonstrated a more rapid reduction in circulating anti-GBM antibodies and better renal function in the group treated with a regimen that included plasma exchange [68].

The standard treatment for anti-GBM disease is intensive daily plasma exchange for at least 2 weeks. Prior to the standard implementation of this treatment regimen, the prognosis of anti-GBM disease was poor; however, current survival rates have been reported to be $75-95 \%$ in several case series. The renal prognosis is dependent on renal function at the time of presentation, with few patients with a creatinine level of $>6.6 \mathrm{mg} / \mathrm{dL}$ recovering sufficient renal function to avoid renal replacement therapy despite aggressive treatment with plasma exchange and immunosuppression $[65,69]$. Anti-GBM disease is rare in children and described in only small case series and case reports 
[70-72]. In these series, patients treated with plasma exchange show a reduction in levels of anti-GBM antibodies, but reported cases of improved renal function are rare $[73,74]$.

Other glomerulonephritis

Therapeutic plasma exchange has been studied in the treatment of other forms of immune-mediated glomerulonephritis, including lupus nephritis and IgA nephropathy, but benefit has not been demonstrated in these diseases. While plasma exchange reduces the levels of circulating lupusassociated antibodies, controlled studies have failed to show improvement in clinical outcomes when patients with lupus nephritis are treated with TPE $[75,76]$ - therefore treatment with TPE is not recommended for use in lupus nephritis. TPE may be beneficial in patients with other life-threatening manifestations of lupus, including diffuse alveolar hemorrhage or central nervous system involvement [3].

The ASFA groups IgA nephropathy and HSP together with other forms of immune-mediated rapidly progressive glomerulonephritis, for which there are no strong data to support the use of TPE [3]. Retrospective studies of children with crescentic HSP nephritis have demonstrated improvement in those treated with TPE alone [77, 78] and in combination with medical immunosuppression [79], although no prospective data exist. Neither HSP nor IgA nephropathy is a recommended indication for TPE at this time [3].

\section{aHUS and thrombotic thrombocytopenic purpura}

Atypical hemolytic uremic syndrome and thrombotic thrombocytopenic purpura (TTP) are rare conditions, but they are the most common thrombotic microangiopathies in children. Both conditions are characterized by hemolytic anemia, thrombocytopenia and variable degrees of renal and cognitive dysfunction caused by systemic microvascular thrombi. aHUS (HUS not associated with Shiga toxin) accounts for approximately $10 \%$ of cases of pediatric HUS and portends a poor renal prognosis, with approximately $50 \%$ of patients progressing to ESRD [80, 81]. In more than $50 \%$ of pediatric aHUS cases, endothelial damage results from an identifiable genetic defect in the complement pathway, including defects in factor $\mathrm{H}$, factor $\mathrm{I}$, factor $\mathrm{B}$, membrane cofactor protein (MCP), thrombomodulin or $\mathrm{C} 3[80,82,83]$. Acquired antibodies to complement factor $\mathrm{H}$ have also been described, mostly in pediatric patients [84, 85]. Other causes of aHUS include calcineurin inhibitor therapy, hematopoietic stem cell transplantation, methylmalonic aciduria (in neonates) and infection with Streptococcus pneumoniae. TTP, which is very rare in children, is caused by a deficient activity of the von-Willebrand factor cleaving protein,
ADAMTS (A Disintegrin And Metalloprotease with ThromboSpondin type 1 motif, member) 13, either resulting from an autosomal recessive mutation in the gene that encodes ADAMTS13 (congenital TTP or UpshawSchulman syndrome) or from an inhibitory antibody to ADAMTS13 (acquired idiopathic TTP). In aHUS and in congenital and acquired TTP, replacement of the deficient factor with donor fresh frozen plasma by TPE or plasma infusion inhibits the process driving the microangiopathy.

Until the recent Federal Drug Administration (FDA) approval of medical therapy with eculizumab (discussed below), the first line treatment for aHUS in children was intensive TPE. No randomized trials are available, but guidelines recommend to initiate TPE if possible within $24 \mathrm{~h}$ of presentation with five daily treatments followed by treatment five times weekly for 2 weeks, then three times weekly for 2 weeks [86]. Hematologic response to therapy is monitored by platelet count, assessment for fragmented red blood cells and lactate dehydrogenase level. Renal response is assessed by measuring renal function, proteinuria and blood pressure [86, 87]. Depending on the patient's response and results of genetic testing, the frequency of therapy can be gradually reduced. Children with aHUS are at high risk of relapse and graft failure after kidney transplantation and, therefore, must be followed closely as the frequency of treatment is decreased $[83,88]$. In adults with TTP, treatment with plasma exchange has been shown to be both beneficial [87] and superior to plasma infusion, so TPE is also recommended for children with congenital TTP [89].

Prognosis and response to TPE differ depending on the underlying causative defect $[84,90]$. While patients with defects in factor $\mathrm{H}$ or factor I have a better response to TPE than those with other complement pathway defects, the rates of progression to ESRD remain high at nearly $70 \%$. Patients with factor $\mathrm{H}$ mutations are often dependent on TPE to achieve and maintain remission of their disease [84, 90-93]. Children with aHUS secondary to mutations in MCP have better renal prognosis, including higher likelihood of complete remission, lower likelihood of progression to ESRD (approx. $20 \%$ ) and lower rates of disease recurrence in the transplanted kidney and death $[90,94]$ - despite the lack of evidence demonstrating a benefit of TPE in this group [84, 90, 94]. Results of genetic testing are usually not available at the time of presentation, so from a practical standpoint, therapy with TPE must be initiated without this knowledge and can be modified once the results are known, if necessary.

Eculizumab, a monoclonal antibody that inhibits C5 to prevent activation of the terminal complement pathway, was designated an Orphan Medicinal Product in the USA and Europe in 2009 and was approved by the FDA for use in aHUS in 2011. Since 2009, several series of pediatric patients with various complement pathway gene defects and aHUS have reported the successful use of eculizumab in patients 
who are treatment naive or who have failed or not tolerated treatment with TPE [95-98]. Eculizumab has also been reported to prevent and treat post-transplant recurrence of aHUS, which is common [90, 97, 99-101]. A prospective, open-label, multicenter clinical trial of eculizumab in pediatric patients with aHUs (http://clinicaltrials.gov NCT01193348) is currently in progress. It is a promising treatment for aHUS and may replace TPE as the recommended first line therapy in the next few years.

\section{Other emerging indications}

Sepsis with multiorgan failure

Therapeutic plasma exchange has been proposed for use in sepsis to remove endotoxins and the circulating cytokines that drive the inflammatory response. In a study including pediatric patients, a reduction in circulating inflammatory mediators and number of failed organs was observed, but there was no improvement in mortality [102]. Other studies have shown a reduction in endotoxin levels [103], and improved 28-day mortality [104]. The benefit of plasma exchange in severe sepsis with multiorgan failure is currently under investigation in a small study of adult patients (Clinicaltrials.gov NCT01249222).

\section{Technical aspects of pediatric plasma exchange}

Therapeutic plasma exchange is an accepted safe and effective therapy in pediatrics; however, automated apheresis machines are designed for use in adults and, therefore, several specific modifications must be considered to ensure safety for use in smaller children.

\section{Techniques}

Two automated techniques are available for plasma exchange: centrifugation and filtration. In smaller children, manual exchanges may also be considered to avoid the relatively large extracorporeal volume required for the automated methods if blood products are not available to prime the circuit.

The majority of the evidence for TPE in adults and children has been described with the use of centrifugal methods, although membrane filtration methods may be equally as effective for most indications. In the centrifugal method, blood is removed from the patient, and the blood components are separated by mechanical centrifugation into layers based on density: plasma, buffy coat and red blood cells. Cellular components, which are kept sterile, are returned to the patient with additional replacement fluid.
The patient's plasma is collected into a waste bag and discarded.

Standard membrane filtration is used less frequently in the pediatric setting. It can be performed using hemodialysis or continuous renal replacement therapy equipment with a plasma filter. The transmembrane pressure forces the plasma through the membrane, and cells and platelets are retained in the blood path. The filtration rate is limited, and a smaller portion of plasma is removed, resulting in longer procedure times to achieve the same reduction in the target molecule. Blood components are separated by size in membrane filtration; thus, the size of molecules removed is limited by the size of the pores of the filter. It is a more selective method than centrifugation and leads to less thrombocytopenia compared with centrifugation [47]. In resource-limited countries, membrane filtration may be preferred because of the limited availability of centrifugal equipment and the reliance on a blood bank to supply blood products to avoid hypovolemia during centrifugal plasma exchange [105]. A group in Ottawa, Canada has published methods of plasma exchange using equipment familiar to the pediatric nephrologist: the Baxter BM25 machine, which is typically used for continuous venovenous hemofiltration. Smaller tubing is available for use in pediatrics, and there are two types of plasma filters [106]. This review will focus on centrifugal methods for plasma exchange, which is the most common method used in pediatrics in the USA and the procedure used for most of the trials described in the various 'Indications' sections of this review.

In critically ill children who require other simultaneous extracorporeal therapies (i.e. continuous renal replacement or extracorporeal membrane oxygenation), TPE can be done in parallel or in series with the other therapy $[4,107,108]$.

\section{Access}

Most children will require a double-lumen, central venous catheter for plasma exchange. In children older than 10 years of age or weighing $>30 \mathrm{~kg}$, discontinuous therapy may be considered. For the latter, only one access site is required, and blood is withdrawn, processed and then reinfused through the same port. Continuous therapy, during which simultaneous withdrawal and infusion occur, is preferred in smaller children to avoid the large shifts in intravascular volume that are necessary for discontinuous therapies. Continuous plasma exchange requires two access ports. In some adolescents with adequate veins, TPE can be performed through two largegauge peripheral intravenous lines, if the child is able to be still with both arms extended for the duration of the procedure. Based on our experience, a 17-gauge steel dialysis needle can be used to draw blood, and an 18-gauge short angiocath can be used to return cells and replacement fluid to the patient. Other groups have reported the use of even smaller needles (18- 
gauge to draw and 22-gauge to return) [47]. Children weighing $<30 \mathrm{~kg}$ require larger central access to achieve adequate blood flow rates to supply the cell separator without collapse of the patient's vessel. The catheters used are the same as those used for pediatric hemodialysis and have the advantage of being stiff enough to tolerate the negative pressure of the apheresis machine without collapse and large enough to allow for adequate blood flow rates, which may be as high as $2 \mathrm{~mL} / \mathrm{kg} / \mathrm{min}$ [109]. Because blood flow rates are lower than those necessary for hemodialysis, a smaller catheter can be used than would be necessary for hemodialysis, and we often place 9 French catheters in our adolescent and adult patients. When using a double-lumen catheter, blood is drawn from the proximal port and returned through the distal port to limit potential recirculation. The internal jugular vein is the preferred site of access; femoral catheters limit mobility and may have increased rates of infection, while subclavian catheters are at higher risk of mechanical failure and long-term vascular stenosis. If a longer duration of treatment is expected, a tunneled cuffed catheter should be placed, although temporary catheters can be used for emergent or single procedures if necessary. To date there have no studies reporting the use of arteriovenous (AV) fistulas or grafts for plasma exchange, although permanent surgical vascular access should be considered for patients who require long-term therapy (i.e. years).

Catheter-related complications are common in pediatric apheresis patients. In one series of pediatric apheresis patients, most of whom had tunneled central access for their procedures, catheter-associated thrombosis occurred in $12.4 \%$ of patients (1.7 \% of procedures) and infection (positive blood culture) occurred in $16.1 \%$ of patients ( $2.1 \%$ of procedures) [110]. This rate of infection (antibiotic course given) is lower than that reported for pediatric hemodialysis patients with indwelling central venous catheters (9\% of procedures) [111]. Infection rates can be reduced by hand-washing and diligent exit site care with chlorhexidine [112].

\section{Sedation}

For the rare child who is very anxious and cannot remain calm and cooperative even with reassurance and distraction provided by their family member(s) and sensitive staff, sedation is possible with benzodiazepines and antihistamines can be used [4].

\section{Extracorporeal blood volume}

The most important adaptation to ensure safety of plasma exchange in smaller children is modification of the treatment to avoid complications of the relatively large extracorporeal blood volume necessary to use the automated apheresis equipment. The blood volume removed acutely from the child at the initiation of plasma exchange is the equivalent of the volume of the circuit, including the centrifuge, associated tubing and blood warmer. Blood volumes for commonly used equipment are included in Table 3. In addition, there is an obligatory red cell mass that is retained in the machine during the procedure to allow for separation of the blood components. This obligatory extracorporeal volume ranges from 200 to $400 \mathrm{~mL}$ depending on which machine is used and can represent a significant percentage of the patient's total blood volume [113]. Patient blood volume can be estimated by using pediatric formulae $[114,115]$ or sex-specific formulae developed in adults, which are determined by height and weight (Table 4) [116]. If the extracorporeal volume exceeds $10-15 \%$ of the patient's blood volume, measures must be taken to avoid hypotension and acute blood loss anemia, and resultant impaired oxygen delivery [47]. By comparison, for a 70-kg adult male, $400 \mathrm{ml}$ (the largest circuit) represents about $8 \%$ of total blood volume (Table 4).

To avoid hypotension and acute blood loss anemia associated with relatively large extracorporeal volume, the circuit can be primed with packed red blood cells (PRBC) diluted to a hematocrit of $35 \%$ with normal saline. After priming with saline, the centrifuge chamber is filled with donor blood. The saline prime is then diverted to the waste bag, and the return line is filled with donor blood [47]. While dilution is standard practice, a recent abstract reported ten children who received TPE with PRBC priming without dilution who did not develop polycythemia or volume overload [117].

With blood priming, successful plasma exchange has been reported in children weighing as little as $3.2 \mathrm{~kg}$ [118]. Most centers do not have a lower weight limit, although some use a lower weight limit of 5 or $10 \mathrm{~kg}$ for initiating TPE [119].

Hypotension is common in pediatric plasma exchange patients, occurring in $14 \%$ of procedures, and fluid boluses are required in almost $5 \%$ of procedures. Identifiable risk factors for hypotension include low patient weight, young age, renal disease, absence of blood primer and hypocalcemia [110]. Whether the patient can tolerate the removal of a large red cell mass without any compromise of their oxygen delivery must be determined based on the clinical circumstances, including volume status, cardiovascular status and hematocrit prior to the procedure.

Table 3 Obligatory extracorporeal volume of equipment for continuous pediatric plasmapheresis

\begin{tabular}{ll}
\hline $\begin{array}{l}\text { Plasmapheresis } \\
\text { equipment }\end{array}$ & $\begin{array}{l}\text { Obligatory extracorporeal } \\
\text { volume of equipment }(\mathrm{mL})\end{array}$ \\
\hline Baxter BM25 plus filter & $\begin{array}{l}\text { Neonatal: } 85-100 \\
\text { Pediatric: } 101-116 \\
\text { Cobe spectra }\end{array}$ \\
Cobe Optia & 170 \\
Fenwal Amicus & 185 \\
\hline
\end{tabular}


Table 4 Equations to estimate total blood volume in children

\begin{tabular}{ll}
\hline Equations & Blood volume \\
\hline Russel 1949 [114] & \\
Weight $(\mathrm{kg})$ & Blood volume $(\mathrm{mL})$ \\
$3-10$ & $58.2 \times$ weight $(\mathrm{kg})+42$ \\
$10-20$ & $82.7 \times$ weight $(\mathrm{kg})+17$ \\
$20-30$ & $95.7 \times$ weight $(\mathrm{kg})-274$ \\
Nadler $1962[115]$ & \\
Sex & Blood volume $(\mathrm{mL})$ \\
Male & $0.3669 \times$ height $(\mathrm{m})^{3}+0.03219 \times$ \\
& weight $(\mathrm{kg})+0.6041$ \\
Female & $0.3561 \times$ height $(\mathrm{m})^{3}+0.03308 \times$ \\
& weight $(\mathrm{kg})+0.1833$ \\
Geigy scientific tables $1970[116]$ & \\
Age & Mean blood volume per \\
& weight $(\mathrm{mL} / \mathrm{kg})$ \\
24 h & 83 \\
3 months & 87 \\
6 months & 86 \\
1 year & 80 \\
6 years & 80 \\
10 years & 75 \\
15 years & 71 \\
Adult men & 71 \\
Adult women & 70 \\
\hline
\end{tabular}

Hypothermia may also result as a consequence of large extracorporeal volume. A blood warmer, which requires an additional $20-50 \mathrm{~mL}$ of extracorporeal volume, can be used to prevent hypothermia in small children.

\section{Anticoagulation}

Regional anticoagulation with sodium citrate has been used for TPE in children for over a decade. Citrate chelates free ionized calcium to prevent activation of the clotting cascade in the extracorporeal circuit. Citrate is preferred to other types of anticoagulation because it is safe, relatively cheap and rapidly cleared in patients with normal hepatic function [120, 121].

The anticoagulant infusion rate is set relative to the blood flow rate, with a goal to achieve adequate anticoagulation of the circuit without inducing systemic toxicity. The manufacturer sets a default blood flow:anticoagulation ratio of 10 $14: 1$. We typically use a ratio of $13-14: 1$ because patients with renal disease clear systemic citrate slower than patients with normal renal function [121]. To avoid systemic hypocalcemia, calcium chloride $(8 \mathrm{~g} / \mathrm{L}$ of normal saline) is infused into a return line at 0.4 -fold the anticoagulant infusion rate, based on protocols developed for pediatric continuous renal replacement therapy. Calcium gluconate $(20 \mathrm{mg} / \mathrm{mL})$ at an infusion rate of $1 \mathrm{~mL} / \mathrm{kg} / \mathrm{h}$ can also be used.
Symptoms of citrate toxicity, including paresthesias, abdominal symptoms and headaches are another common adverse event in pediatric apheresis. Young children are often unable to communicate early symptoms of hypocalcemia, so frequent monitoring of serum ionized calcium and adjustment of the calcium infusion rate to maintain serum ionized calcium at levels of $>1 \mathrm{mEq} / \mathrm{L}$ is recommended. For patient's receiving fresh frozen plasma (FFP) for replacement fluids, there may be an increased incidence of metabolic alkalosis and an increased calcium infusion requirement during the procedure due to a higher citrate load [122].

Unfractionated heparin anticoagulation has also been used for pediatric plasma exchange, with a target activated clotting time of 180-210 s. Multiple factors that contribute to a higher bleeding risk, including decreased coagulation factors and platelets, make heparin a less frequently utilized choice.

\section{Determinants of substance removal/TPE prescription}

The appropriate apheresis prescription depends on the characteristics of the pathogenic molecule that is targeted for removal. These characteristics include its volume of distribution, its equilibrium between the plasma space and the extravascular and intracellular compartments, and its rate of synthesis and catabolism. The volume of plasma processed, the frequency of therapy and the duration of therapy are modified to achieve maximum removal of the pathogenic molecule.

\section{Volume to process}

During each exchange, pathogenic molecules are removed only from the plasma space, such that molecules with a smaller volume of distribution (i.e. IgM) are removed more efficiently than molecules with a larger volume of distribution (i.e. IgG). Molecules that rapidly equilibrate between the plasma space and extravascular and intracellular space can be more efficiently removed as the plasma space is replenished during the treatment. In the simplest model, the relationship between the removal of plasma constituents and volume processed during a treatment with plasma exchange demonstrates exponential decay, such that efficiency is reduced as higher exchange volumes are achieved [123]. When a 1.5-fold plasma volume exchange is performed, 63$72 \%$ of the original plasma components are removed, but extending the procedure beyond 1.5-fold plasma volume does not provide much additional benefit in the removal of the pathogenic molecules (Fig. 1). Because of this, each treatment aims to remove 1- to 1.5 -fold the patient's plasma volume. Plasma volume is calculated as:

Plasma volume $=$ Blood volume $(1-$ Hematocrit $/ 100)$ 


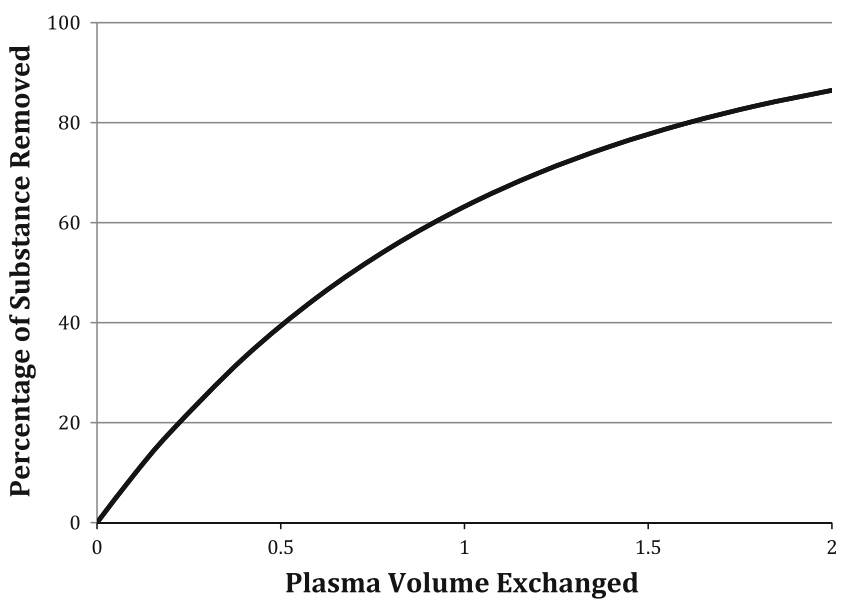

Fig. 1 The percentage of pathologic substance removed with a single treatment of plasma exchange can be calculated as $\%=\mathrm{e}^{\wedge}$ (plasma volume removed/patient plasma volume)

Frequency and duration of treatment

After depletion with TPE, the plasma level of the pathogenic molecule rebounds as it redistributes from the extravascular space back to the plasma space and as ongoing synthesis occurs. The rate and magnitude of rebound is determined by the characteristics of the molecule in question. For example, $\mathrm{IgM}$, which is a large molecule, is distributed mostly in the intravascular space, and therefore the total body level of IgM is efficiently reduced with plasma exchange. This is the case in Waldenstrom's macroglobulinemia, in which the associated hyperviscosity can be treated effectively with one or two treatments. IgG and IgA, on the other hand, distribute in the extravascular space in addition to the intravascular space, so while $\operatorname{IgA}$ and $\operatorname{IgG}$ are cleared at a similar rate to that of $\operatorname{IgM}$, they reaccumulate in the plasma space more quickly, and diseases mediated by $\operatorname{IgA}$ and $\operatorname{IgG}$ thus require more frequent plasma exchange. This has recently been described in mathematical models which are beyond the scope of this article [124]. In addition, synthesis can be modified with concurrent use of immunosuppression in most conditions. For most disease processes, TPE frequency is tapered as the markers of the disease activity improve.

\section{Replacement fluids}

The replacement fluids used in children are the same as those used in adults. In aHUS and TTP, FFP is used to replace removed plasma. In other conditions, $5 \%$ albumin alone or a combination of colloid ( $5 \%$ albumin) and normal saline can be used, usually at a ratio of 2:1 albumin:saline. If frequent (daily) treatments are required or if the patient does not have normal synthesis of coagulation factors (i.e. fibrinogen $<100 \mathrm{mg} / \mathrm{dL}$ prior to treatment), partial replacement with FFP can be used to restore normal coagulation.
Other complications of plasma exchange

Complication rates in adult series are low at approximately $5 \%$ (excluding transient paresthesias and mild vasovagal events), with higher rates among patients who receive plasma compared with those who do not [125]. Children appear to be at higher risk for complications, including more hypotension, symptomatic hypocalcemia, allergic reactions, severe anemia and catheter infection or thrombosis, affecting up to $55 \%$ of procedures and $82 \%$ of patients. Lower body weight, higher number of procedures and lower hemoglobin were associated with more events [110]. The most common adverse reactions (hypotension secondary to high extracorporeal volume, citrate toxicity and catheter-related complications) are discussed above. There are several other complications that should also be considered, including medication removal, transfusion reactions, removal of beneficial immunoglobulins, and impaired coagulation. These are discussed below.

\section{Medication removal}

Medications with a low volume of distribution and which are highly protein bound may be removed by TPE at rates that affect their efficacy. For children undergoing plasma exchange for renal indications, the most important considerations are immunoglobulins, including IVIG, basiliximab and rituximab [126]. Some commonly used antibiotics (cephalosporins, vancomycin) or antiepileptic medications (phenytoin, valproate) may require supplementation or dosing after TPE when possible. On the other hand, corticosteroids, cyclosporine and tacrolimus are only minimally removed by TPE.

\section{Complications of transfusion with human blood products}

Complications of transfusion with human blood products introduce additional risks for patients who require blood priming or FFP with the procedure, including transmission of viral infections and transfusion reactions such as hemolysis and acute lung injury. The risk of transmission of viral infections is extremely low in the USA, where blood products are screened extensively. The rate of any non-infectious complication of blood product transfusion is approximately 11 per 1,000 units transfused in a large pediatric population [127]. To avoid transfusion reactions, we typically give acetaminophen $(15 \mathrm{mg} / \mathrm{kg})$ and diphenhydramine $(1 \mathrm{mg} / \mathrm{kg})$ prior to transfusion. If the patient has had a transfusion reaction in the past, corticosteroids can be used in addition to the above-mentioned prophylactic medications.

\section{Removal of immunoglobulins}

Therapeutic plasma exchange not only removes pathogenic molecules but also normal immunoglobulins, and immunoglobulin 
levels have been demonstrated to be lower in patients undergoing plasma exchange [128, 129]. This does not appear to be associated with a higher rate of infection [128], and levels have been shown to return to baseline after 35 days [129]. Some investigators have suggested that FFP supplementation as part of replacement fluids be used in actively infected plasma exchange patients with IgG levels of $<100 \mathrm{mg} / \mathrm{dL}$ [130]. In patients undergoing frequent plasma exchange, low-dose IVIG $(100-150 \mathrm{mg} / \mathrm{kg} / \mathrm{dose})$ infusions have also been used to avoid hypogammaglobulinemia [49].

\section{Depletion of coagulation factors}

Levels of coagulation factors are transiently depleted by TPE without FFP supplementation [129]. Most coagulation factors are rapidly synthesized by the liver, and in patients with normal hepatic function, prothrombin time and partial thromboplastin time normalize within $24 \mathrm{~h}$, and fibrinogen normalizes within 48-72 h [129]. Fibrinogen levels should be checked prior to plasma exchange, especially in patients undergoing therapy more frequently than every other day. It is generally agreed that replacement with partial or full volume FFP should be used to avoid bleeding complications if fibrinogen levels are $<100 \mathrm{mg} / \mathrm{dL}$ prior to a TPE treatment. For patients undergoing TPE in the $48 \mathrm{~h}$ before or after surgical procedures, including central venous catheter placement, we recommend replacement with partial or full volume FFP to avoid potential bleeding complications.

\section{Electrolyte abnormalities}

There is potential for hypokalemia when the replacement solution used is albumin as it contains a potassium level of $<2 \mathrm{mEq} / \mathrm{L}$. Aluminium toxicity has been reported in the past, particularly in patients with impaired renal function due to elevated aluminium content of some albumin preparations. Finally, as discussed above metabolic alkalosis may result from the use of citrate anticoagulation or FFP. Electrolytes should be monitored closely and deficiencies replaced as necessary.

Bradykinin release syndrome

Patients on angiotensin converting enzyme-inhibitors, which inhibit bradykinin breakdown, can develop atypical reactions during plasma exchange because TPE can activate kinins. Reactions can be mild (flushing and hypotension) or rarely can result in anaphylactic reactions, so it is generally recommended that ACEinhibitors be avoided in patients undergoing plasma exchange [131].

\section{Conclusion}

Therapeutic plasma exchange is a safe and effective therapy in children with a variety of renal diseases, but requires specialized care and practitioners experienced in the care of children to meet their specialized needs. More data, especially in children, are necessary to assess the benefit of TPE in these and other renal conditions.

\section{Multiple choice questions (answers appear following the references)}

1. Plasma exchange is accepted as a first-line therapy for treatment of these conditions EXCEPT:

a) Recurrent FSGS

b) Antibody-mediated kidney allograft rejection

c) Lupus nephritis

d) ANCA-associated rapidly progressive glomerulonephritis and dialysis dependence

e) Atypical HUS due to autoantibody to factor $\mathrm{H}$

2. Which of the following complication is NOT associated with citrate anticoagulation
a) Hypocalcemia
b) Hypotension
c) Metabolic alkalosis
d) Hypokalemia
e) Paresthesias

3. A 10-year-old girl presents with anemia, thrombocytopenia and renal failure. A diagnosis of aHUS is made and plasma exchange initiated. The replacement solution to be used should be:

a) Albumin $5 \%$

b) A combination of albumin 5\% and normal saline

c) Packed red blood cells

d) Fresh frozen plasma

4. A 2-year-old boy (weight $10 \mathrm{~kg}$ ) is 1-year post-renal transplant. He has evidence of acute antibodymediated rejection on transplant biopsy. Therapy with automated equipment for plasma exchange is considered. Which of the following statement is TRUE:

a) Plasma exchange cannot be performed because he is too young

b) A combination of albumin and normal saline can be used for the replacement fluid

c) The circuit should not be primed with blood products

d) Peripheral venous access can be used for the procedure 


\section{References}

1. Abel JJ, Rowntree LG, Turner BB (1914) Plasma removal with return of corpuscles. J Pharmacol Exp Ther 5:625-641

2. Schwab PJ, Fahey JL (1960) Treatment of Waldenstrom's macroglobulinemia by plasmapheresis. N Engl J Med 263:574-579

3. Szczepiorkowski ZM, Winters JL, Bandarenko N, Kim HC, Linenberger ML, Marques MB, Sarode R, Schwartz J, Weinstein R, Shaz BH (2010) Guidelines on the use of therapeutic apheresis in clinical practice-evidence-based approach from the Apheresis Applications Committee of the American Society for Apheresis. J Clin Apher 25:83-177

4. Balogun RA, Kaplan A, Ward DM, Okafor C, Burns TM, Torloni AS, Macik BG, Abdel-Rahman EM (2010) Clinical applications of therapeutic apheresis. J Clin Apher 25:250-264

5. Cecka JM, Kucheryavaya AY, Reinsmoen NL, Leffell MS (2011) Calculated PRA: initial results show benefits for sensitized patients and a reduction in positive crossmatches. Am J Transplant 11:719-724

6. Stegall MD, Gloor J, Winters JL, Moore SB, Degoey S (2006) A comparison of plasmapheresis versus high-dose IVIG desensitization in renal allograft recipients with high levels of donorspecific alloantibody. Am J Transplant 6:346-351

7. Akalin E, Dinavahi R, Friedlander R, Ames S, de Boccardo G, Sehgal V, Schroppel B, Bhaskaran M, Lerner S, Fotino M, Murphy B, Bromberg JS (2008) Addition of plasmapheresis decreases the incidence of acute antibody-mediated rejection in sensitized patients with strong donor-specific antibodies. Clin J Am Soc Nephrol 3:1160-1167

8. Thielke JJ, West-Thielke PM, Herren HL, Bareato U, Ommert T, Vidanovic V, Campbell-Lee SA, Tzvetanov IG, Sankary HN, Kaplan B, Benedetti E, Oberholzer J (2009) Living donor kidney transplantation across positive crossmatch: the University of Illinois at Chicago experience. Transplantation 87:268-273

9. Montgomery RA, Lonze BE, King KE, Kraus ES, Kucirka LM, Locke JE, Warren DS, Simpkins CE, Dagher NN, Singer AL, Zachary AA, Segev DL (2011) Desensitization in HLAincompatible kidney recipients and survival. N Engl $\mathrm{J}$ Med 365:318-326

10. Pradhan M, Raffaelli RM, Lind C, Meyers KE, Kaplan BS, Baluarte HJ, Monos D (2008) Successful deceased donor renal transplant in a sensitized pediatric recipient with the use of plasmapheresis. Pediatr Transplant 12:711-716

11. Vo AA, Lukovsky M, Toyoda M, Wang J, Reinsmoen NL, Lai $\mathrm{CH}$, Peng A, Villicana R, Jordan SC (2008) Rituximab and intravenous immune globulin for desensitization during renal transplantation. N Engl J Med 359:242-251

12. Vo AA, Peng A, Toyoda M, Kahwaji J, Cao K, Lai CH, Reinsmoen NL, Villicana R, Jordan SC (2010) Use of intravenous immune globulin and rituximab for desensitization of highly HLA-sensitized patients awaiting kidney transplantation. Transplantation 89:1095-1102

13. Jordan SC, Vo AA (2012) Desensitization offers hope to highly HLA-sensitized patients for a longer life expectancy after incompatible kidney transplant. Am J Kidney Dis 59:758-760

14. Wu A, Buhler LH, Cooper DK (2003) ABO-incompatible organ and bone marrow transplantation: current status. Transpl Int $16: 291-299$

15. Winters JL, Gloor JM, Pineda AA, Stegall MD, Moore SB (2004) Plasma exchange conditioning for $\mathrm{ABO}$-incompatible renal transplantation. J Clin Apher 19:79-85

16. Ishida H, Koyama I, Sawada T, Utsumi K, Murakami T, Sannomiya A, Tsuji K, Yoshimura N, Tojimbara T, Nakajima I, Tanabe K, Yamaguchi Y, Fuchinoue S, Takahashi K, Teraoka S, Ito K, Toma H, Agishi T (2000) Anti-AB titer changes in patients with $\mathrm{ABO}$ incompatibility after living related kidney transplantations: survey of 101 cases to determine whether splenectomies are necessary for successful transplantation. Transplantation 70:681-685

17. Tobian AA, Shirey RS, Montgomery RA, Cai W, Haas M, Ness PM, King KE (2010) ABO antibody titer and risk of antibodymediated rejection in $\mathrm{ABO}$-incompatible renal transplantation. Am J Transplant 10:1247-1253

18. Tobian AA, Shirey RS, Montgomery RA, Tisch DJ, Ness PM, King KE (2009) Therapeutic plasma exchange reduces ABO titers to permit $\mathrm{ABO}$-incompatible renal transplantation. Transfusion 49:1248-1254

19. Sivakumaran P, Vo AA, Villicana R, Peng A, Jordan SC, Pepkowitz SH, Klapper EB (2009) Therapeutic plasma exchange for desensitization prior to transplantation in $\mathrm{ABO}$-incompatible renal allografts. J Clin Apher 24:155-160

20. Shishido S, Hyodo YY, Aoki Y, Takasu J, Kawamura T, Sakai KK, Aikawa AA, Satou H, Muramatsu MM, Matsui Z (2012) Outcomes of pediatric $\mathrm{ABO}$-incompatible kidney transplantations are equivalent to ABO-compatible controls. Transplant Proc 44:214-216

21. Shishido S, Asanuma H, Tajima E, Hoshinaga K, Ogawa O, Hasegawa A, Honda M, Nakai H (2001) ABO-incompatible living-donor kidney transplantation in children. Transplantation 72:1037-1042

22. Takahashi K, Saito K, Takahara S, Okuyama A, Tanabe K, Toma H, Uchida K, Hasegawa A, Yoshimura N, Kamiryo Y (2004) Excellent long-term outcome of ABO-incompatible living donor kidney transplantation in Japan. Am J Transplant 4:1089-1096

23. Genberg H, Kumlien G, Wennberg L, Berg U, Tyden G (2008) ABO-incompatible kidney transplantation using antigen-specific immunoadsorption and rituximab: a 3-year follow-up. Transplantation 85:1745-1754

24. Tyden G, Kumlien G, Berg UB (2011) ABO-incompatible kidney transplantation in children. Pediatr Transplant 15:502-504

25. Puttarajappa C, Shapiro R, Tan HP (2012) Antibody-mediated rejection in kidney transplantation: a review. J Transplant 2012:193724

26. Dragun D (2007) Agonistic antibody-triggered stimulation of Angiotensin II type 1 receptor and renal allograft vascular pathology. Nephrol Dial Transplant 22:1819-1822

27. Reinsmoen NL, Lai CH, Heidecke H, Haas M, Cao K, Ong G, Naim M, Wang Q, Mirocha J, Kahwaji J, Vo AA, Jordan SC, Dragun D (2010) Anti-angiotensin type 1 receptor antibodies associated with antibody-mediated rejection in donor HLA antibody negative patients. Transplantation 90:1473-1477

28. Solez K, Colvin RB, Racusen LC, Haas M, Sis B, Mengel M, Halloran PF, Baldwin W, Banfi G, Collins AB, Cosio F, David DS, Drachenberg C, Einecke G, Fogo AB, Gibson IW, Glotz D, Iskandar SS, Kraus E, Lerut E, Mannon RB, Mihatsch M, Nankivell BJ, Nickeleit V, Papadimitriou JC, Randhawa P, Regele H, Renaudin K, Roberts I, Seron D, Smith RN, Valente M (2008) Banff 07 classification of renal allograft pathology: updates and future directions. Am J Transplant 8:753-760

29. Jordan SC, Reinsmoen N, Peng A, Lai CH, Cao K, Villicana R, Toyoda M, Kahwaji J, Vo AA (2010) Advances in diagnosing and managing antibody-mediated rejection. Pediatr Nephrol 25:2035-2045, quiz 2045-2038

30. Ahmed T, Senzel L (2012) The role of therapeutic apheresis in the treatment of acute antibody-mediated kidney rejection. J Clin Apher 27:173-177

31. Rocha PN, Butterly DW, Greenberg A, Reddan DN, TuttleNewhall J, Collins BH, Kuo PC, Reinsmoen N, Fields T, Howell DN, Smith SR (2003) Beneficial effect of plasmapheresis and intravenous immunoglobulin on renal allograft survival of patients with acute humoral rejection. Transplantation 75:1490 1495 
32. Brown CM, Abraham KA, O'Kelly P, Conlon PJ, Walshe JJ (2009) Long-term experience of plasmapheresis in antibodymediated rejection in renal transplantation. Transplant Proc 41:3690-3692

33. Gomes AM, Pedroso S, Martins LS, Malheiro J, Viscayno JR, Santos J, Dias L, Henriques AC, Sarmento AM, Cabrita A (2009) Diagnosis and treatment of acute humoral kidney allograft rejection. Transplant Proc 41:855-858

34. Kranz B, Kelsch R, Kuwertz-Broking E, Brocker V, Wolters HH, Konrad M (2011) Acute antibody-mediated rejection in paediatric renal transplant recipients. Pediatr Nephrol 26:1149-1156

35. Lefaucheur C, Nochy D, Andrade J, Verine J, Gautreau C, Charron D, Hill GS, Glotz D, Suberbielle-Boissel C (2009) Comparison of combination Plasmapheresis/IVIg/anti-CD20 versus high-dose IVIg in the treatment of antibody-mediated rejection. Am J Transplant 9:1099-1107

36. Bohmig GA, Wahrmann M, Regele H, Exner M, Robl B, Derfler K, Soliman T, Bauer P, Mullner M, Druml W (2007) Immunoadsorption in severe C4d-positive acute kidney allograft rejection: a randomized controlled trial. Am J Transplant 7:117-121

37. Savin VJ, Sharma R, Sharma M, McCarthy ET, Swan SK, Ellis E, Lovell H, Warady B, Gunwar S, Chonko AM, Artero M, Vincenti F (1996) Circulating factor associated with increased glomerular permeability to albumin in recurrent focal segmental glomerulosclerosis. N Engl J Med 334:878-883

38. Wei C, Trachtman H, Li J, Dong C, Friedman AL, Gassman JJ, McMahan JL, Radeva M, Heil KM, Trautmann A, Anarat A, Emre S, Ghiggeri GM, Ozaltin F, Haffner D, Gipson DS, Kaskel F, Fischer DC, Schaefer F, Reiser J (2012) Circulating suPAR in two cohorts of primary FSGS. J Am Soc Nephrol 23:2051-2059

39. Fine RN (2007) Recurrence of nephrotic syndrome/focal segmental glomerulosclerosis following renal transplantation in children. Pediatr Nephrol 22:496-502

40. Hickson LJ, Gera M, Amer H, Iqbal CW, Moore TB, Milliner DS, Cosio FG, Larson TS, Stegall MD, Ishitani MB, Gloor JM, Griffin MD (2009) Kidney transplantation for primary focal segmental glomerulosclerosis: outcomes and response to therapy for recurrence. Transplantation 87:1232-1239

41. Senggutuvan P, Cameron JS, Hartley RB, Rigden S, Chantler C, Haycock G, Williams DG, Ogg C, Koffman G (1990) Recurrence of focal segmental glomerulosclerosis in transplanted kidneys: analysis of incidence and risk factors in 59 allografts. Pediatr Nephrol 4:21-28

42. Hubsch H, Montane B, Abitbol C, Chandar J, Shariatmadar S, Ciancio G, Burke G, Miller J, Strauss J, Zilleruelo G (2005) Recurrent focal glomerulosclerosis in pediatric renal allografts: the Miami experience. Pediatr Nephrol 20:210-216

43. Artero M, Biava C, Amend W, Tomlanovich S, Vincenti F (1992) Recurrent focal glomerulosclerosis: natural history and response to therapy. Am J Med 92:375-383

44. Fuentes GM, Meseguer CG, Carrion AP, Hijosa MM, GarciaPose A, Melgar AA, Torres MN (2010) Long-term outcome of focal segmental glomerulosclerosis after pediatric renal transplantation. Pediatr Nephrol 25:529-534

45. Andresdottir MB, Ajubi N, Croockewit S, Assmann KJ, Hibrands LB, Wetzels JF (1999) Recurrent focal glomerulosclerosis: natural course and treatment with plasma exchange. Nephrol Dial Transplant 14:2650-2656

46. Deegens JK, Andresdottir MB, Croockewit S, Wetzels JF (2004) Plasma exchange improves graft survival in patients with recurrent focal glomerulosclerosis after renal transplant. Transpl Int 17:151-157

47. Greenstein SM, Delrio M, Ong E, Feuerstein D, Schechner R, Kim D, Corey H, Kaskel R, Tellis VA, Moritz ML (2000) Plasmapheresis treatment for recurrent focal sclerosis in pediatric renal allografts. Pediatr Nephrol 14:1061-1065
48. Fencl F, Simkova E, Vondrak K, Janda J, Chadimova M, Stejskal J, Seeman T (2007) Recurrence of nephrotic proteinuria in children with focal segmental glomerulosclerosis after renal transplantation treated with plasmapheresis and immunoadsorption: case reports. Transplant Proc 39:3488-3490

49. Cochat P, Kassir A, Colon S, Glastre C, Tourniaire B, Parchoux B, Martin X, David L (1993) Recurrent nephrotic syndrome after transplantation: early treatment with plasmaphaeresis and cyclophosphamide. Pediatr Nephrol 7:50-54

50. Schachter AD, Harmon WE (2001) Single-center analysis of early recurrence of nephrotic syndrome following renal transplantation in children. Pediatr Transplant 5:406-409

51. Ohta T, Kawaguchi H, Hattori M, Komatsu Y, Akioka Y, Nagata M, Shiraga H, Ito K, Takahashi K, Ishikawa N, Tanabe K, Yamaguchi Y, Ota K (2001) Effect of pre-and postoperative plasmapheresis on posttransplant recurrence of focal segmental glomerulosclerosis in child, 52en. Transplantation 71:628-633

52. Couloures K, Pepkowitz SH, Goldfinger D, Kamil ES, Puliyanda DP (2006) Preventing recurrence of focal segmental glomerulosclerosis following renal transplantation: a case report. Pediatr Transplant 10:962-965

53. Jungraithmayr TC, Hofer K, Cochat $P$, Chernin G, Cortina G, Fargue S, Grimm P, Knueppel T, Kowarsch A, Neuhaus T, Pagel P, Pfeiffer KP, Schafer F, Schonermarck U, Seeman T, Toenshoff B, Weber S, Winn MP, Zschocke J, Zimmerhackl LB (2011) Screening for NPHS2 mutations may help predict FSGS recurrence after transplantation. J Am Soc Nephrol 22:579-585

54. Dall'Amico R, Ghiggeri G, Carraro M, Artero M, Ghio L, Zamorani E, Zennaro C, Basile G, Montini G, Rivabella L, Cardillo M, Scalamogna M, Ginevri F (1999) Prediction and treatment of recurrent focal segmental glomerulosclerosis after renal transplantation in children. Am J Kidney Dis 34:1048-1055

55. Baum MA (2004) Outcomes after renal transplantation for FSGS in children. Pediatr Transplant 8:329-333

56. Gonzalez E, Ettenger R, Rianthavorn P, Tsai E, Malekzadeh M (2011) Preemptive plasmapheresis and recurrence of focal segmental glomerulosclerosis in pediatric renal transplantation. Pediatr Transplant 15:495-501

57. Gohh RY, Yango AF, Morrissey PE, Monaco AP, Gautam A, Sharma M, McCarthy ET, Savin VJ (2005) Preemptive plasmapheresis and recurrence of FSGS in high-risk renal transplant recipients. Am J Transplant 5:2907-2912

58. de Lind van Wijngaarden RA, Hauer HA, Wolterbeek R, Jayne DR, Gaskin G, Rasmussen N, Noel LH, Ferrario F, Waldherr R, Bruijn JA, Bajema IM, Hagen EC, Pusey CD (2007) Chances of renal recovery for dialysis-dependent ANCA-associated glomerulonephritis. J Am Soc Nephrol 18:2189-2197

59. Jayne DR, Gaskin G, Rasmussen N, Abramowicz D, Ferrario F, Guillevin L, Mirapeix E, Savage CO, Sinico RA, Stegeman CA, Westman KW, van der Woude FJ, de Lind van Wijngaarden RA, Pusey CD (2007) Randomized trial of plasma exchange or highdosage methylprednisolone as adjunctive therapy for severe renal vasculitis. J Am Soc Nephrol 18:2180-2188

60. Zauner I, Bach D, Braun N, Kramer BK, Funfstuck R, Helmchen U, Schollmeyer P, Bohler J (2002) Predictive value of initial histology and effect of plasmapheresis on long-term prognosis of rapidly progressive glomerulonephritis. Am J Kidney Dis 39:28-35

61. Cole E, Cattran D, Magil A, Greenwood C, Churchill D, Sutton D, Clark W, Morrin P, Posen G, Bernstein K (1992) A prospective randomized trial of plasma exchange as additive therapy in idiopathic crescentic glomerulonephritis. The Canadian Apheresis Study Group. Am J Kidney Dis 20:261-269

62. Akikusa JD, Schneider R, Harvey EA, Hebert D, Thorner PS, Laxer RM, Silverman ED (2007) Clinical features and outcome of pediatric Wegener's granulomatosis. Arthritis Rheum 57:837844 
63. Nash MC, Jones CL, Walker RG, Powell HR (1993) Antineutrophil cytoplasmic antibody-associated glomerulonephritis in children. Pediatr Nephrol 7:11-14

64. Stegmayr BG, Gothefors L, Malmer B, Muller Wiefel DE, Nilsson K, Sundelin B (2000) Wegener granulomatosis in children and young adults. A case study of ten patients. Pediatr Nephrol 14:208-213

65. Levy JB, Turner AN, Rees AJ, Pusey CD (2001) Long-term outcome of anti-glomerular basement membrane antibody disease treated with plasma exchange and immunosuppression. Ann Intern Med 134:1033-1042

66. Martini A, Binda S, Mariani G, Scotta MS, Ruberto G (1981) Goodpasture's syndrome in a child: natural history and effect of treatment. Acta Paediatr Scand 70:435-439

67. Shah MK, Hugghins SY (2002) Characteristics and outcomes of patients with Goodpasture's syndrome. South Med J 95:1411-1418

68. Johnson JP, Moore J Jr, Austin HA 3rd, Balow JE, Antonovych TT, Wilson CB (1985) Therapy of anti-glomerular basement membrane antibody disease: analysis of prognostic significance of clinical, pathologic and treatment factors. Medicine (Baltimore) 64:219-227

69. Pusey CD (2003) Anti-glomerular basement membrane disease. Kidney Int 64:1535-1550

70. Williamson SR, Phillips CL, Andreoli SP, Nailescu C (2011) A 25-year experience with pediatric anti-glomerular basement membrane disease. Pediatr Nephrol 26:85-91

71. Dewan D, Gulati S, Sharma RK, Prasad N, Jain M, Gupta A, Kumar A (2008) Clinical spectrum and outcome of crescentic glomerulonephritis in children in developing countries. Pediatr Nephrol 23:389-394

72. Jardim HM, Leake J, Risdon RA, Barratt TM, Dillon MJ (1992) Crescentic glomerulonephritis in children. Pediatr Nephrol 6:231-235

73. Gilvarry J, Doyle GF, Gill DG (1992) Good outcome in antiglomerular basement membrane nephritis. Pediatr Nephrol 6:244-246

74. Bakkaloglu SA, Kasapkara CS, Soylemezoglu O, Peru H, Fidan K, Hasanoglu E, Buyan N (2006) Successful management of antiGBM disease in a $51 / 2$-year-old girl. Nephrol Dial Transplant 21:2979-2981

75. Lewis EJ, Hunsicker LG, Lan SP, Rohde RD, Lachin JM (1992) A controlled trial of plasmapheresis therapy in severe lupus nephritis. The Lupus Nephritis Collaborative Study Group. N Engl J Med 326:1373-1379

76. Wallace DJ, Goldfinger D, Pepkowitz SH, Fichman M, Metzger AL, Schroeder JO, Euler HH (1998) Randomized controlled trial of pulse/synchronization cyclophosphamide/apheresis for proliferative lupus nephritis. J Clin Apher 13:163-166

77. Hattori M, Ito K, Konomoto T, Kawaguchi H, Yoshioka T, Khono M (1999) Plasmapheresis as the sole therapy for rapidly progressive Henoch-Schonlein purpura nephritis in children. Am J Kidney Dis 33:427-433

78. Shenoy M, Ognjanovic MV, Coulthard MG (2007) Treating severe Henoch-Schonlein and IgA nephritis with plasmapheresis alone. Pediatr Nephrol 22:1167-1171

79. Kawasaki Y, Suzuki J, Murai M, Takahashi A, Isome M, Nozawa R, Suzuki S, Suzuki H (2004) Plasmapheresis therapy for rapidly progressive Henoch-Schonlein nephritis. Pediatr Nephrol 19:920-923

80. Besbas N, Karpman D, Landau D, Loirat C, Proesmans W, Remuzzi G, Rizzoni G, Taylor CM, Van de Kar N, Zimmerhackl LB (2006) A classification of hemolytic uremic syndrome and thrombotic thrombocytopenic purpura and related disorders. Kidney Int 70:423-431

81. Loirat C, Noris M, Fremeaux-Bacchi V (2008) Complement and the atypical hemolytic uremic syndrome in children. Pediatr Nephrol 23:1957-1972
82. Noris M, Remuzzi G (2005) Genetic abnormalities of complement regulators in hemolytic uremic syndrome: how do they affect patient management? Nat Clin Pract Nephrol 1:2-3

83. Geerdink LM, Westra D, van Wijk JA, Dorresteijn EM, Lilien MR, Davin JC, Komhoff M, Van Hoeck K, van der Vlugt A, van den Heuvel LP, van de Kar NC (2012) Atypical hemolytic uremic syndrome in children: complement mutations and clinical characteristics. Pediatr Nephrol 27:1283-1291

84. Noris M, Remuzzi G (2010) Genetics and genetic testing in hemolytic uremic syndrome/thrombotic thrombocytopenic purpura. Semin Nephrol 30:395-408

85. Dragon-Durey MA, Sethi SK, Bagga A, Blanc C, Blouin J, Ranchin B, Andre JL, Takagi N, Cheong HI, Hari P, Le Quintrec M, Niaudet P, Loirat C, Fridman WH, FremeauxBacchi V (2010) Clinical features of anti-factor $\mathrm{H}$ autoantibodyassociated hemolytic uremic syndrome. J Am Soc Nephrol 21:2180-2187

86. Ariceta G, Besbas N, Johnson S, Karpman D, Landau D, Licht C, Loirat C, Pecoraro C, Taylor CM, Van de Kar N, Vandewalle J, Zimmerhackl LB (2009) Guideline for the investigation and initial therapy of diarrhea-negative hemolytic uremic syndrome. Pediatr Nephrol 24:687-696

87. Bukowski RM, King JW, Hewlett JS (1977) Plasmapheresis in the treatment of thrombotic thrombocytopenic purpura. Blood 50:413-417

88. Bresin E, Daina E, Noris M, Castelletti F, Stefanov R, Hill P, Goodship TH, Remuzzi G (2006) Outcome of renal transplantation in patients with non-Shiga toxin-associated hemolytic uremic syndrome: prognostic significance of genetic background. Clin $\mathrm{J}$ Am Soc Nephrol 1:88-99

89. Rock GA, Shumak KH, Buskard NA, Blanchette VS, Kelton JG, Nair RC, Spasoff RA (1991) Comparison of plasma exchange with plasma infusion in the treatment of thrombotic thrombocytopenic purpura. Canadian Apheresis Study Group. N Engl J Med 325:393-397

90. Sellier-Leclerc AL, Fremeaux-Bacchi V, Dragon-Durey MA, Macher MA, Niaudet P, Guest G, Boudailliez B, Bouissou F, Deschenes G, Gie S, Tsimaratos M, Fischbach M, Morin D, Nivet H, Alberti C, Loirat C (2007) Differential impact of complement mutations on clinical characteristics in atypical hemolytic uremic syndrome. J Am Soc Nephrol 18:2392-2400

91. Kim JJ, Goodship TH, Tizard J, Inward C (2011) Plasma therapy for atypical haemolytic uraemic syndrome associated with heterozygous factor H mutations. Pediatr Nephrol 26:2073-2076

92. Nathanson S, Fremeaux-Bacchi V, Deschenes G (2001) Successful plasma therapy in hemolytic uremic syndrome with factor H deficiency. Pediatr Nephrol 16:554-556

93. Landau D, Shalev H, Levy-Finer G, Polonsky A, Segev Y, Katchko L (2001) Familial hemolytic uremic syndrome associated with complement factor H deficiency. J Pediatr 138:412-417

94. Caprioli J, Noris M, Brioschi S, Pianetti G, Castelletti F, Bettinaglio P, Mele C, Bresin E, Cassis L, Gamba S, Porrati F, Bucchioni S, Monteferrante G, Fang CJ, Liszewski MK, Kavanagh D, Atkinson JP, Remuzzi G (2006) Genetics of HUS: the impact of $\mathrm{MCP}, \mathrm{CFH}$, and IF mutations on clinical presentation, response to treatment, and outcome. Blood 108:1267-1279

95. Ariceta G, Arrizabalaga B, Aguirre M, Morteruel E, LopezTrascasa M (2012) Eculizumab in the treatment of atypical hemolytic uremic syndrome in infants. Am J Kidney Dis 59:707710

96. Tschumi S, Gugger M, Bucher BS, Riedl M, Simonetti GD (2011) Eculizumab in atypical hemolytic uremic syndrome: long-term clinical course and histological findings. Pediatr Nephrol 26:2085-2088

97. Gruppo RA, Rother RP (2009) Eculizumab for congenital atypical hemolytic-uremic syndrome. N Engl J Med 360:544-546 
98. Lapeyraque AL, Fremeaux-Bacchi V, Robitaille P (2011) Efficacy of eculizumab in a patient with factor-H-associated atypical hemolytic uremic syndrome. Pediatr Nephrol 26:621-624

99. Nester C, Stewart Z, Myers D, Jetton J, Nair R, Reed A, Thomas C, Smith R, Brophy P (2011) Pre-emptive eculizumab and plasmapheresis for renal transplant in atypical hemolytic uremic syndrome. Clin J Am Soc Nephrol 6:1488-1494

100. Zimmerhackl LB, Hofer J, Cortina G, Mark W, Wurzner R, Jungraithmayr TC, Khursigara G, Kliche KO, Radauer W (2010) Prophylactic eculizumab after renal transplantation in atypical hemolytic-uremic syndrome. N Engl J Med 362:1746-1748

101. Weitz M, Amon O, Bassler D, Koenigsrainer A, Nadalin S (2011) Prophylactic eculizumab prior to kidney transplantation for atypical hemolytic uremic syndrome. Pediatr Nephrol 26:1325-1329

102. Reeves JH, Butt WW, Shann F, Layton JE, Stewart A, Waring PM, Presneill JJ (1999) Continuous plasmafiltration in sepsis syndrome. Plasmafiltration in Sepsis Study Group. Crit Care Med 27:2096-2104

103. Bengsch S, Boos KS, Nagel D, Seidel D, Inthorn D (2005) Extracorporeal plasma treatment for the removal of endotoxin in patients with sepsis: clinical results of a pilot study. Shock 23:494-500

104. Busund R, Koukline V, Utrobin U, Nedashkovsky E (2002) Plasmapheresis in severe sepsis and septic shock: a prospective, randomised, controlled trial. Intensive Care Med 28:1434-1439

105. Sinha A, Tiwari AN, Chanchlani R, Seetharamanjaneyulu V, Hari P, Bagga A (2012) Therapeutic plasmapheresis using membrane plasma separation. Indian J Pediatr 79:1084-1086

106. Ciechanska E, Segal L, Wong H, Chretien C, Feber J, Filler G (2005) Plasma exchange using a continuous venovenous hemofiltration machine in children. Blood Purif 23:440-445

107. Yorgin PD, Eklund DK, al-Uzri A, Whitesell L, Theodorou AA (2000) Concurrent centrifugation plasmapheresis and continuous venovenous hemodiafiltration. Pediatr Nephrol 14:18-21

108. Jhang J, Middlesworth W, Shaw R, Charette K, Papa J, Jefferson R, Torloni AS, Schwartz J (2007) Therapeutic plasma exchange performed in parallel with extra corporeal membrane oxygenation for antibody-mediated rejection after heart transplantation. J Clin Apher 22:333-338

109. Bunchman TE, Brophy PD, Goldstein SL (2008) Technical considerations for renal replacement therapy in children. Semin Nephrol 28:488-492

110. Michon B, Moghrabi A, Winikoff R, Barrette S, Bernstein ML, Champagne J, David M, Duval M, Hume HA, Robitaille N, Belisle A, Champagne MA (2007) Complications of apheresis in children. Transfusion 47:1837-1842

111. Zaritsky JJ, Salusky IB, Gales B, Ramos G, Atkinson J, Allsteadt A, Brandt ML, Goldstein SL (2008) Vascular access complications in long-term pediatric hemodialysis patients. Pediatr Nephrol 23:2061-2065

112. Maki DG, Ringer M, Alvarado CJ (1991) Prospective randomised trial of povidone-iodine, alcohol, and chlorhexidine for prevention of infection associated with central venous and arterial catheters. Lancet 338:339-343

113. Goldstein SL, Klaus G, Friedman DF, Kim HC (2012) Pediatric therapeutic apheresis. In: Warady (ed) Pediatric dialysis. Springer, New York, pp 775-796

114. Russell SJ (1949) Blood volume studies in healthy children. Arch Dis Child 24:88-98

115. JR Geigy AG, Diem K, Lentner C (1970) Geigy Scientific Tables, 7th Edition, Basel, Switzerland

116. Nadler SB, Hidalgo JH, Bloch T (1962) Prediction of blood volume in normal human adults. Surgery 51:224-232
117. Pinkard SL, O’Leary MF, Carey PM (2012) Blood priming for apheresis on the COBE spectra: should red cell units be diluted or not? Abstracts from the American Society for Apheresis 33rd Annual Meeting, April 11-14, 2012, Atlanta, Georgia. J Clin Apher 27:30

118. Jung S, Kang ES, Ki CS, Kim DW, Paik KH, Chang YS (2011) Successful therapeutic plasma exchange in a $3.2-\mathrm{kg}$ body weight neonate with atypical hemolytic uremic syndrome. J Clin Apher $26: 162-165$

119. Delaney MSS, Capocelli KE, Schneiderman J, Wong EC, Eder A, Kim HC (2012) A survey of pediatric apheresis practice. Abstracts from the American Society for Apheresis 33rd Annual Meeting, April 11-14, 2012, Atlanta, Georgia. J Clin Apher 27:2

120. Kramer L, Bauer E, Joukhadar C, Strobl W, Gendo A, Madl C, Gangl A (2003) Citrate pharmacokinetics and metabolism in cirrhotic and noncirrhotic critically ill patients. Crit Care Med 31:2450-2455

121. Lee G, Arepally GM (2012) Anticoagulation techniques in apheresis: from heparin to citrate and beyond. J Clin Apher 27:117125

122. Antonic M, Gubensek J, Buturovic-Ponikvar J, Ponikvar R (2009) Comparison of citrate anticoagulation during plasma exchange with different replacement solutions. Ther Apher Dial $13: 322-326$

123. Reverberi R, Reverberi L (2007) Removal kinetics of therapeutic apheresis. Blood Transfus 5:164-174

124. Hattersley JG, Chappell MJ, Zehnder D, Higgins RM, Evans ND (2012) Describing the effectiveness of immunosuppression drugs and apheresis in the treatment of transplant patients. Comput Meth Programs Biomed 109:126-133

125. McLeod BC, Sniecinski I, Ciavarella D, Owen H, Price TH, Randels MJ, Smith JW (1999) Frequency of immediate adverse effects associated with therapeutic apheresis. Transfusion 39:282-288

126. Ibrahim RB, Liu C, Cronin SM, Murphy BC, Cha R, Swerdlow P, Edwards DJ (2007) Drug removal by plasmapheresis: an evidence-based review. Pharmacotherapy 27:1529-1549

127. Slonim AD, Joseph JG, Turenne WM, Sharangpani A, Luban NL (2008) Blood transfusions in children: a multi-institutional analysis of practices and complications. Transfusion 48:73-80

128. Pohl MA, Lan SP, Berl T (1991) Plasmapheresis does not increase the risk for infection in immunosuppressed patients with severe lupus nephritis. The Lupus Nephritis Collaborative Study Group. Ann Intern Med 114:924-929

129. Wood L, Jacobs P (1986) The effect of serial therapeutic plasmapheresis on platelet count, coagulation factors, plasma immunoglobulin, and complement levels. J Clin Apher 3:124-128

130. Hanafusa N (2011) Theoretical basis of pathogenic substance removal during plasmapheresis. Ther Apher Dial 15:421-430

131. Brecher ME, Owen HG, Collins ML (1993) Apheresis and ACE inhibitors. Transfusion 33:963-964 